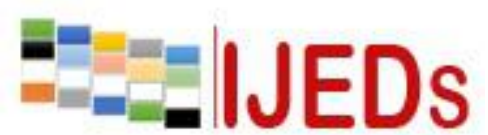

http://ijeds.ppj.unp.ac.id/index.php/IJEDS

\title{
THE DEVELOPMENT OF LEARNING MATERIALS-BASED GUIDED NARRATIVE WRITING SKILLS WRITING IN ELEMENTARY SCHOOL
}

\author{
*Lika Apreasta ${ }^{1}$, Firman $^{2}$ and Darnis Arief ${ }^{2}$ \\ ${ }^{1}$ College Student Primary Education, FIP Universitas Negeri Padang, Indonesia \\ ${ }^{2}$ PGSD lecture, FIP Universitas Negeri Padang, Indonesia \\ Email: lika.didi93@gmail.com
}

*Corresponding Author, Received: November 12, 2018, Revised: December 10, 2018, Accepted: December 21, 2018

\begin{abstract}
Effected by the use of materials that are less able to attract students and writing less in accordance with the process of writing (pramenulis, saatmenulis, and pascamenulis). The goals achieved in the efforts of the development of these materials is to produce learning materials to write a narrative-based Guided Writing for teachers and students of class V SD a valid, practical, and effective. This type of research is research development. This research uses a 4-D model which consists of 4 stages: stage define, design, develop, and disseminate. Test the validity of the data obtained through the assessment of the response sheet teacher and students. The effectiveness of the activity seen from the students, assessment processes and results of narrative writing students. Based on the results of test validity, practicalities, and effectiveness of the materials obtained a valid, practical, and effective, as well as being able to enhance the narrative writing skills of students. It can be concluded that the materials to write a narrative using Guided Writing developed can be used in learning to write narratives in class $\mathrm{V}$ primary school.
\end{abstract}

Keywords: Guided Writing, Narrative Writing, Learning Materials

\section{INTRODUCTION}

Writing is productive skills by using writings, and developing and pouring thoughts into a regular writing structure (Mulyati, 2009). A lot of research on writing skills, such as in the USA (Muslims, 2014), Malaysia (Togatorop, 2015), Malaysia (Pawliczak, 2015), USA (Siddiqui, 2015), the research States that are able to create awareness of the learner about the importance of writing in accordance with the steps writing. Writing skills that are taught in the students have a goal to achieve, such as advanced Abidin (2012) the essential minimum that there are three main goals of 


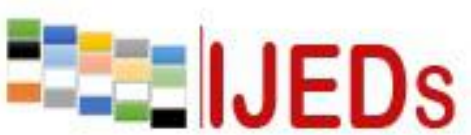

http://ijeds.ppj.unp.ac.id/index.php/IJEDS
International Journal of Educational Dynamics

Vol. 1 No. 1 (pp. 155-161) December 2018

p_ISSN 2655-4852

e ISSN 2655-5093

learning to write in elementary school, namely: (1) foster passion for writing on a self learner, (2) develop writing skills learners, (3) build the soul of creativity of learners to write.

This type of writing skills that must be mastered in elementary learners one is narrative writing skills. Hermon and Dalim (2006); Saddhono (2012) narrative (narrative or pengisahan) is a variety of a discourse which describes the process of occurrence of an event. Research writing narrative are also carried out by the experts of which, in Indonesia (Beads and clear Sinurat, 2015), menjukkan research results that by using the film as a medium of learning can increase the value of writing narrative learners with the average reach 84.3. Indonesia (Hermon and Dalim, 2005; Asrifan, 2015), the results of the research was to teach writing by using image series can be meningkakant the ability to write narratives in SMA Negeri 3 cities Pare. Indonesia (Zacharias, 2014), the results showed that the role of the teachers in learners can interact with a menungkatkan the results of writing narrative. Narrative writing skills are very important for learners of them as a means to help learners in expressing his feelings as well as the surrounding environment can understand so that learners are able to pour the ideas to in narrative writing betuk.

Based on the results of preliminary studies researchers at grade V SD Negeri 03 Sitiung Dharmasraya in narrative writing study found some problems, such as: (1) learning to write the narrative still do with told the students to write a narrative within a specified time, and then collected. (2) the students are less guided in menentukakan topics and framework for the bouquet. (3) the resulting writing the learners did not have a clear flow. (4) the students are less guided in the use of punctuation, spelling and capitalization are correct. (5) teachers and learners still fixated with outstanding materials and are used in the schools. (6) approaches and strategies used less teachers in accordance with learning to write, so the learner difficulties in organizing idea or notion. Similar problems were also found by Atmazaki (2006) and Nixon (2012).

Based on the above exposure seen need for materials that are practical and effective. learning to write narratives that require materials namely learners who sesuasi with the stages of writing, namely pramenulis, saatmenulis, and pascamenulis. One strategy that can be used in developing learning materials to write a narrative strategy is 


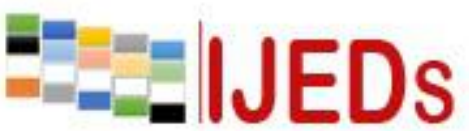

http://ijeds.ppj.unp.ac.id/index.php/IJEDS

\section{International Journal of Educational Dynamics}

Vol. 1 No. 1 (pp. 155-161) December 2018

p_ISSN 2655-4852

e ISSN 2655-5093

to use Guided Writing. This is evidenced in the study using a strategy Guided Writing done by some experts, in Indonesia (Reyhan, 2011), the results of the study revealed that with Guided Writing and picture series can improve writing students. Indonesia (Anggrainy, 2016), results of the study revealed that there is a significant difference in the achievement after writing with strategy Guided Writing. Indonesia (Ningsih, 2016), results of the study revealed that the strategy Guided Writing can overcome the problems in writing skills in MTs Almuna Samarinda. Nigeria (Timayi, 2015), the results of the study revealed that by using strategies Guided Writing looks a significant difference in the achievement score experimental group have a higher value. Pakistan (Khatri, 2014), the results of the study revealed that the results of writing narrative learners with Guided Writing more effective.

\section{METHOD}

This research is research development (Research and Development). Sukmadinata (2010) revealed that development research is a process or steps to develop a new product or refining existing products, as well as socially. Development in research on model using the model development of 4-D (four D model). Sugiyono (2009:404) describes the stages of 4-D model include: "definition (define), design (design), development (develop), and dissemination (disseminate)". At this stage of the analysis conducted define curriculum, needs analysis, and the analysis of the students. The results of this analysis to be used as reference in designing a learning materials (design). Next on stage design (design), which is designing learning materials using Guided Writing in class V SD. After materials finished designed, then do (develop) against the aforesaid materials SDN 03 Sitiung Dharmasraya with number of students is 20 people. The development phase include validity, practicalities, and effectiveness. Stages of the validity of the linguistic content, aspect, and kegrafikaan materials. The instrument used is the validation contents sheet materials, sheet materials, linguistic validation and validation kegrafikaan sheet materials. The next stage of the practicalities, aims to see the level of convenience and practicality of learning materials developed. The instruments used are observation sheet keterlaksaan RPP, now the response sheet 


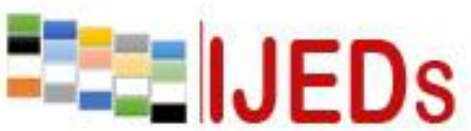

http://ijeds.ppj.unp.ac.id/index.php/IJEDS

teacher, and now student response sheet. Then on the stage of effectiveness are performed to find out whether or not the objectives are achieved or expected to its full potential through learning materials developed. The instruments used are the student activity sheet observations against the effectiveness of the assessment sheet, process narrative, writing skills and writing skills appraisal sheet narrative. The next phase of the deployment is performed (disseminate) to see the effectiveness of learning materials developed. the deployment is done in 18 Sitiung SDN Dharmasraya, with the number of students 18 people. This is done to see keefektivitasan learning materials at other schools, with environmental conditions and different students.

\section{RESULTS AND DISCUSSION}

The results of the research on the development of learning materials to write a narrative using Guided Writing in class V SD seen from the level of validity, practicalities, and effectiveness.

\section{Validity}

Validation is performed against the materials to write a narrative using Guided Writing is emphasized on the contents and invalid constructs. Validation materials as seen from several aspects, which comprises aspects of content, language, and kegrafikaan. Validation in this research was conducted by 5 people the appropriate experts with validator field, i.e. its 3 people expert content and validator kebahasaaan validator, 3 people kegrafikaan experts, as well as 3 people validator practitioners who derived from primary school teachers. Validation said to be completed, if the validator declares valid towards learning materials, so that it is ready to do a test run. The results of the validation of the validator experts showed that the learning materials to write a narrative using Guided Writing 93.7\% earn a percentage very valid criteria. Meanwhile, from the validator practitioners earn a percentage $94.4 \%$ with very valid criteria. The validity of learning materials to write a narrative using Guided Writing in class $\mathrm{V}$ primary school developed in this research was valid in terms of contents and invalid constructs. This is in accordance with the results of the validation of the validator the 


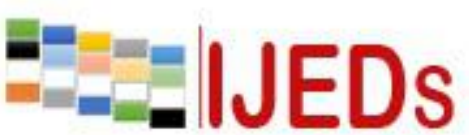

http://ijeds.ppj.unp.ac.id/index.php/IJEDS

\section{International Journal of Educational Dynamics}

Vol. 1 No. 1 (pp. 155-161) December 2018

p_ISSN 2655-4852

e ISSN 2655-5093

validator education experts and practitioners. This result gives an idea that materials developed have been valid and can be used in the learning process.

\section{Practicalities}

After the validation process with experts and practitioners of education completed, conducted trials to look at the practicalities of learning materials to write the narrative. A test done by as much as 3 times the meeting, observed by 2 persons observer. Practicalities of the observed level of RPP, keterlaksanaan is the now the response of teachers, and the student's response is now against the practicalities of learning devices. The results of the observation when trials show that learning occurs in compliance with planning that have been created with the percentage obtained $88.81 \%$ by category is very practical. While the results of the response of teachers now earn a percentage $920.1 \%$ by category is very practical, and now the response of students earn a percentage $88.60 \%$ by category is very practical. This suggests that the learning materials to write a narrative using Guided Writing developed very practical use in the process of learning to write narratives in class V SD.

\section{The effectiveness of the}

Learning materials are said to be effective in giving effect or influence to the achievement of the learning objectives. The effectiveness of the learning materials as seen from the student's activities while learning and assessment of the process of learning to write narratives as well as the results of narrative writing skills of students. Based on the results of data analysis against the activity of the students when learning $91.10 \%$ percentage gain with excellent category, while the assessment of the learning process of writing narrative students obtain category $84.25 \%$ by category is very high, then the results of narrative writing skills students gained $86.96 \%$ by category percentage is very high. Student activity observations, assessment process, and an assessment of the results of the student's narrative writing gives an excellent overview, meaning the use of learning materials in learning to write narratives already effectively implemented. 


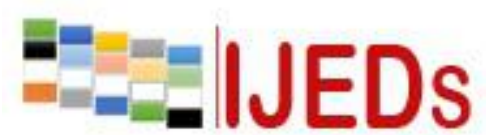

http://ijeds.ppj.unp.ac.id/index.php/IJEDS
International Journal of Educational Dynamics

Vol. 1 No. 1 (pp. 155-161) December 2018

p_ISSN 2655-4852

e_ISSN 2655-5093

\section{CONCLUSION}

Based on the development and trials that have been done to the learning materials to write a narrative using Guided Writing in class V primary school that the development of learning materials to write a narrative using Guided Writing aspects of validity, indicating that the These materials have very valid criteria, both in terms of content as well as in terms of invalid constructs. This is in accordance with the results of the validation of the validator the validator education experts and practitioners. This result gives an idea that narrative writing materials developed have been valid and can be used in the learning process. The results showed that the practicalities of learning materials is very practical, both in terms of keterpakaian as well as in terms of implementation. These results are seen from keterlaksanaan RPP, now yield response of teachers, and the student response now. The results of the effectiveness of students pointed out that the development of learning materials to write a narrative using Guided Writing in class V SD has been declared effective to increase the achievement of students ' writing skills.

\section{REFERENCES}

Abidin, Y. 2012. Pembelajaran Bahasa Berbasis Pendidikan Karakter. Bandung: PT. Refika Aditama.

Anggrainy, S. 2016. The Effect of Graphic Organizers, Guided Writing Strategies, and Reading Levels on the Writing Achievement of The Fourth Semester Students of PGMI Program at IAIN Raden Intan Lampung. Proceedings of the 2nd SULE - IC 2016, FKIP, Unsri, Palembang.

Asrifan, A. 2015. The Use of Pictures Story in Improving Students Ability to Write Narrative Composition. International Journal of Language and Linguistics. Vol.3, No.4, 244-251. ISSN: 2330-0205 (Print); ISSN: 2330-0221

Atmazaki. 2006. Kiat-kiat Mengarang dan Menyunting. Padang: Yayasan Citra Budaya Indonesia.

Hermon, D and Y. Dalim. 2005. Penggunaan Media Audio Visual untuk Meningkatkan Kreatifitas Belajar. Jurnal Pembelajaran. Vol. 28. Issue 3. p. 266-276

Hermon, D and Y. Dalim. 2006. Penerapan Kuliah Lapangan untuk Meningkatkan Hasil Belajar Mahasiswa. Forum Pendidikan. Vol. 28. Issue 3. p. 156-161

Khatri, D, K. 2014. Effectiveness of Guided Writing in Teaching Composition. Journal of NELTA Surkhet Vol. 4 December, 2014.

Mulyati, Y. 2009. Keterampilan Berbahasa Indonesia SD. Jakarta: Universitas Terbuka.

Muslim, I, M. 2014. Helping efl Students Improve their Writing. International Journal of Humanities and Social Science. Vol.4, No.2, 105-112. 
http://ijeds.ppj.unp.ac.id/index.php/IJEDS

Ningsih, S. 2016. Guided Writing to Improve the Students Writing Ability of Junior High School Students. EFL JOURNAL Vol. 1 No. 2, 2016 www.efljournal.org e-ISSN: 2502-6054, p-ISSN: 2527-5089 doi: http://dx.doi.org/10.21462/eflj.v1i2.12

Pawliczak, J. 2015. Creative Writing as a Best Way to Improve Writing Skills of Students. Sino-US English Teaching David Publising, Vol. 12, No. 5, 347-352 doi:10.17265/1539-8072/2015.05.004.

Reyhan, A. 2011.The Use of Guided Writing and Sequences of Pictures as Teaching Technique to Enhance the Ability of Writing Narrative of Students in Different English Course. Indonesia.

Saddhono, K and S.Y.Slamet. 2012. Meningkatkan Keterampilan Berbahasa Indonesia (Teori dan Aplikasi). Bandung: Karya Putra Darwati.

Sugiyono. 2009. Metode Penelitian Kuantitaif, Kualitatif Dan R \&D. Bandung: Alfabeta.

Timayi, C. 2015. Impact of Guided Writing Strategy on Junior Secondary School Students Writing Competence in Kaduna State, Nigeria. 2015; 2(3): 45-49 Published online $\quad$ August
(http://www.openscienceonline.com/journal/eris).

Togatorop, E. 2015. Teaching Writing with a Web Based Collaborative Learning. International Journal of Economics and Financial Issues. Vol.5, special issue, ISSN: $2146-4138$.

Zacharias, N, T. 2014. Second Language Teacher Contributions to Student Classroom Participation: a Narrative Study of Indonesian Learners. ELTWorldOnline.com May 2014 http://blog.nus.edu.sg/eltwo/?p=4358 Volume 6 ISSN 1793-8732 